\title{
J'ACCUSE COMO FATO LITERÁRIO: UMA LEITURA DA CARTA ABERTA DE ÉMILE ZOLA Milene SUZANO
}

RESUMO : A partir da metodologia de análise de Leo Spitzer, o presente texto busca colocar em movimento os elementos literários da carta J'accuse, escrita por Émile Zola, em janeiro de 1898. A enorme repercussão da carta na época tem sido constantemente associada à influência da imprensa de massa e aos recursos retóricos tão habilmente utilizados por Zola. Mas, além dos elementos persuasivos e do fator imprensa, a personificação das figuras reais e a adjetivação polarizante dos personagens reais são, em grande medida, frutos de construções literárias. A partir destes dois elementos (adjetivação e personificação), o objetivo do texto é propor uma análise de trechos da carta, dos textos de polêmica de Zola e de seus romances nos quais se manifesta semelhante procedimento.

PALAVRAS-CHAVE: estilística, J'accuse, imprensa, Émile Zola, carta aberta.

\footnotetext{
${ }^{1}$ Doutora em Letras pela Universidade de São Paulo - mail : milenesuzano@gmail.com
} 


\title{
J'ACCUSE COMME UN FAIT LITTÉRAIRE: UNE LECTURE DE LA LETTRE OUVERTE D'ÉMILE ZOLA
}

RÉSUMÉ : Basé sur la métodologie de Leo Spitzer, cet article cherche à mettre en movement la construction littéraire de J'accuse, lettre ouverte d'Émile Zola, publiée en janvier 1898. Son importante réception à l'époque a été souvent associée à l'influence de la grande presse et aux recours réthoriques bien utilisés par Zola. Mais au delà de ces elements de persuasion, la personnification des personnages réels et la construction d'un monde dual sont, en grande partie, les conséquences d'une composition littéraire bien élaborée. À partir de ces deux elements (l'usage des adjectifs et la personification), le but de cet article est de proposer une analyse de quelques parties de la lettre, en les liant aux écrits polémiques de Zola et à quelqu'uns de ses romans, où la même procédure peut être vue.

MOTS-CLÉS : la stylistique, J'accuse, la presse, Émile Zola, la lettre ouverte.

\section{INTRODUÇÃO}

No último dia 13 de janeiro de 2018 completaram-se 120 anos da publicação da carta aberta de Émile Zola, J'Accuse, no jornal l'Aurore. J'accuse foi um momento de ruptura na história do caso Dreyfus. O caso começa em 1894 com a prisão do capitão Alfred Dreyfus até a sua reabilitação e reintegração ao Exército em julho de 1906, estando então já falecido o autor da missiva.A carta talvez seja a grande narrativa do caso. Mais do que isso, foi um momento de ruptura. A luta entre os que apoiavam a revisão do processo (dreyfusards) e os contrários à revisão (antidreyfusards) toma a partir de então o ar de combate, que envolve todo o espectro da política francesa. A compreensão desta ruptura foi elaborada pela filósofa Hannah Arendt (1976), em artigo sobre o caso Dreyfus, no qual separa o caso Dreyfus (Dreyfus affaire) do processo Dreyfus (Dreyfus case):

\begin{abstract}
Enquanto o caso Dreyfus nos seus amplos aspectos políticos pertence ao século XX, o processo Dreyfus, os vários julgamentos do capitão judeu Alfred Dreyfus, são bastante típicos do século XIX, quando as pessoas acompanhavam os procedimentos legais tão ansiosamente pois cada instância oferecia um teste para a grande conquista do século, a completa imparcialidade da lei. ${ }^{2}$ (ARENDT, 1976: 91)
\end{abstract}

O processo secreto e militar adentra outro universo, no qual há um público ansioso pelos acontecimentos e pelo desfecho final. É neste mesmo sentido que vai a

\footnotetext{
2 Tradução da autora.
} 
interpretação de $J^{\prime} a c c u s e p o r$ Henri Mitterand (1990)3. Segundo Mitterand, o teor revolucionário da carta está no inquestionável valor simbólico da missiva, a qual confere ao texto um caráter emblemático, ultrapassandoa intervenção circunstancial e mobilizando a opinião:

É a parte da literatura, a parte do estilo, que transfigura o sentido do panfleto, transforma a história em mito e dá ao Caso um 'público' - no sentido dramático do termo - o que o Estado buscava evitar a todo custo. (MITTERAND, 1990: 247)

A impressão é corroborada por Alain Pagès (2003) que trata da interpretação literária na trama dos acontecimentos. Segundo Pagès, Zola escreveu pensando antes de tudo num enredo. Para o crítico, Zola acreditava que, ao escrever J'accuse, ele desenvolveria mais tarde tal enredo, o qual seria um dia transformado em romance. Apesar de ter abandonado essa ideia, na época, a carta teria servido como um dossiê, método recorrentemente utilizado pelo autor em seus romances.

Um elemento interessante está na espécie de criação de um personagem Dreyfus, do qual curiosamente o próprio capitão chegou a se distanciar. Segundo Jean-Denis Bredin (1993), Dreyfus chegou a expressar a um dreyfusard que "O Dreyfus símbolo da Justiça não sou eu ... Este Dreyfus fostes vós que o criastes”. Para o capitão o que importava era a comprovação de sua inocência. Bredin chega a afirmar que "foi dito e repetido que Dreyfus, se não fosse Dreyfus, seria antidreyfusard" (BREDIN, 1993: 560).

E é exatamente a partir da publicação de J'accuse que toma forma o mito Dreyfus, assim como se amplifica o público ávido de novos "capítulos" do caso, como em um feuilleton. Mas, o que faz da carta, do ponto de vista de seu estilo, este ponto de ruptura entre dois séculos, dois públicos e dois Dreyfus? A resposta a esta questão é o objeto central a ser examinado pelo presente texto.

\section{A CARTA ABERTA E O LEITOR}

J'accuse é uma carta aberta, endereçada ao presidente da República francesa, Felix Faure, publicada no jornal l'Aurore, em 13 de janeiro de 1898, tratando do caso Dreyfus e escrita por Émile Zola. A inversão da ordem de descrição não é casual. Seria esperada a indicação do expedidor da carta como primeira referência, ainda mais considerada a importância de Zola na história literária da época. A inversão, porém, restabelece uma voz ausente no discurso: o leitor. Para quem esta-

\footnotetext{
${ }^{3}$ Miterrand é um dos maiores especialistas na obra de Zola. Ele é responsável pelas edições das obras completas do autor, assim como pela edição da Gallimard da série LesRougouMacquart. Tradução da autora.
} 
va sendo escrita esta carta? Realmente para o presidente da República ou para todos aqueles que Zola acusa? Para todos os franceses ou somente para aqueles que acreditavam na potencial inocência do então ex-capitão francês, Alfred Dreyfus? Quem é então o receptor ausente da missiva?

J'accuse é explicitamente dirigida ao presidente Felix Faure em seu início, com uma espécie de elogio ao destinatário - não desprovido de ironia. O destinatário é retomado ao fim de cada uma das partes ${ }^{4}$ e no início e fim da última parte, a derradeira acusação. Esta explicitação ostensiva não deixa dúvidas, em um primeiro momento, quanto ao verdadeiro receptor da missiva. Porém, pelo simples fato de ter sido publicada em um veículo de comunicação de massa, este receptor se torna um pouco mais problemático. É certamente o presidente da República, mas é também o leitor do jornal e, potencialmente, todos aqueles que a leem doravante. Neste sentido, um destinatário velado pode de alguma forma estar sinalizado no texto. A voz do outro, deste receptor universal, surge principalmente nos momentos nos quais se explicita o caráter de conversação. E a carta, como gênero literário, envolve este recurso dialógico de oralidade e conversação.

Dietmar Schmitz (1991), em uma retomada da teoria da arte epistolar e da conversação nas tradições latina e neolatina, dentre outros autores antigos, retoma Quintiliano, em Institutio oratória, em cuja obra fala-se de dois tipos de cartas: uma que se assemelha à conversação e outra que trata de temas políticos e filosóficos. Assim como Quintiliano, grande parte da tradição antiga, segundo Schmitz, divide as cartas entre gênero prazeroso ou familiar e gênero sério ou político. Em J'accuse, apesar do caráter político que envolve a questão abordada, há também um tom familiar em diversos momentos. Além das referências diretas e elogios ao presidente Felix Faure, Zola introduz alguns dos parágrafos do texto com desabafos: "Ah! Cette première affaire, elle est un cauchemar, pour qui la connît dans ses détails vrais !". Este desabafo, mais do que qualquer teor de denúncia, enuncia uma aproximação com o leitor potencial da carta, talvez, o mesmo leitor de seus romances.

O recurso de aproximação se repete no início do parágrafo seguinte: "Ah! Le néant de cetacte d'accusation!". A frase, marcada pela exclamação confere à sentença umtom de desabafo, reforçando uma busca de cumplicidade do leitor. Em outros momentos, a aproximação com este leitor potencial apresenta-se inclusive pela inclusão pronominal: "Et nous arrivons à l'affaire Esterhazy". Zola encaminha o leitor pelo desvelamento da verdade. Como um escritor ciente da necessária pactuação com o seu leitor, Zola o conduz não necessariamente pelos fatos, mas pelos recursos que dispõe como romancista e polemista.

\footnotetext{
${ }^{4}$ A carta é dividida em cinco partes: 1 . Introdução e elogio ao destinatário, 2. O primeiro processo Dreyfus, 3. O processo Esterhazy, 4. Interpretação dos fatos, 5. A acusação.
} 
Portanto, além do caráter explicitamente político de uma carta aberta ${ }^{5}$, existe em $J$ 'accuse uma perspectiva de leitura que se equivale à leitura literária, uma possibilidade de interpretação que se alimenta das camadas de leituras feitas no decorrer do tempo. Proponho aqui, portanto, tratar a carta não mais na sua existência original de carta aberta e datada, mas sim como um fato literário. Tynianov mostra como a existência de um fato como fato literário depende de sua qualidade diferencial: "Uma carta a um amigo de Derjavina é um fato da vida social; na época de Karamzine e de Puchkine, a mesma carta amigável é um fato literário. Dão testemunho disto o caráter literário das memórias e dos diários num sistema literário e seu caráter extraliterário num outro" (TYNIANOV, 1978:131). Tynianov examina o estabelecimento deste fato literário a partir de duas funções: uma determinada pela correlação de outras séries e outras obras (autônoma) e outra com a função construtiva deste elemento (sínoma). Portanto, pensar a hibridez de J'accuse seria pensá-la na sua relação construtiva (análise estrutural) determinada pela correlação com outras referências e contextos. Tratá-la como fato literário é colocar, sob a perspectiva da leitura, a obra em movimento.

Pois a pergunta passa a ser então: se outros escreveram sobre o caso Dreyfus, no mesmo período, muitas vezes políticos com o dom da oratória e da persuasão, como e por que foi somente com o texto de Zola que a situação se polariza a tal ponto que a sociedade francesa se vê então cindida ideologicamente entre dreyfusards e antidreyfusards? A imprensa de massa é um dos aspectos que explicam o retumbante impacto da carta, assim como os recursos oratórios de conhecimento do autor. Mas não são suficientes. Pensar, portanto, a carta como fato literário é um exercício de atualização da leitura. A carta aberta continua a ter seu caráter eminentemente político, porém, analisada hoje, os recursos literários nela contidos proporcionam não somente uma atualização formal, mas uma possível ampliação de seus horizontes estéticos.

\section{OBRA EM DIÁLOGO}

J'accuse contém um discurso ${ }^{6}$ híbrido. E no caso particular de Émile Zola, o ato da escrita se constrói com recursos que vão além do documento de denúncia política. Há traços de sua produção ensaística, de sua teoria do romance e principalmente de sua produção romanesca naturalista. Partindo da carta, a intenção é vis-

\footnotetext{
${ }^{5}$ A ideia de carta aberta é eminentemente política. Em geral, consta de alguma acusação que deve vir a público para que a situação de injustiça seja modificada ou, ao menos, conhecida em seus meandros.

${ }^{6}$ Utilizo aqui a concepção de discurso de Paul Ricœur, em Teoria da Interpretação. O discurso compreende um texto escrito cuja origem não pode ser compreendida integralmente na sua produção e deve ser na leitura interpretado a partir da tríade conjuntura, validação, interpretação; traduzíveis por hipótese, explicação e compreensão crítica. A análise da estrutura do texto fornece as chaves de explicação que permitem a passagem de uma compreensão ingênua para a crítica. Ver Ricœur (1978).
} 
lumbrar a hibridez na forma de elaboração ${ }^{7}$ da missiva; hibridez esta que o especialista na obra de Zola, Henri Mitterand, reconhece no naturalismo do escritor.

De acordo com Henri Mitterand (1990), há no naturalismo zoliano uma tripla e indissociável relação textual entre seu trabalho como ensaísta, como "teórico" do naturalismo e como romancista, sendo a base discursiva de sua obra estruturada a partir da composição binária entre um imaginário biológico, portador de uma linguagem 'mitológica' - um "avant-textegénetique” e um imaginário político, portador imediato de um discurso retórico, como espaço sociocultural. Sobre estas duas dimensões, Mitterand afirma:

Mas, as pesquisas deverão levar em conta o fato que o primeiro elemento deste imaginário provém de uma história dos acontecimentos e dos conceitos científicos e filosóficos de longa data, enquanto que o segundo vem de uma história recente - ainda que corroborada por uma retórica e uma mitologia (...). É suficiente insistir na necessidade de avaliar com cuidado as mediações que unem e distinguem o avanttexte genético e seu espaço sociocultural. ${ }^{8}$ (MITTERAND, 1990:52)

O duplo "avant-textegénétique" e "espace socioculurel” organizariam, desta forma, toda a produção escrita de Zola, seja nos ensaios sobre a pintura impressionista, seja no seu programa genético ou na obra romanesca. Assim, também na carta aberta, haveria uma associação entre o fator político, de caráter imediato, e o elemento mítico levado à condição universal. Seguindo o mesmo raciocínio, Mitterand transfere o projeto para J'accuse:

É a parte da literatura, do estilo, que transfigura o sentido do panfleto, transforma a história em mito e dá ao caso um 'público', no sentido dramático do termo - o que o Estado buscava evitar a qualquer preço. ${ }^{9}$ (MITTERAND, 1990: 247).

Na análise de $J$ 'accuse, a articulação se daria então, segundo Mitterand, a partir da transformação do sentido histórico do panfleto pela parte do estilo, da literatura. E essa transformação de alcance imediato em mito se daria exatamente, segundo o especialista, na construção de um público, ou melhor, de uma audiência para o caso. Já foram sugeridos anteriormente alguns exemplos desta estratégia

\footnotetext{
${ }^{7}$ É importante ressaltar que a utilização de vários recursos não vem da intenção explícita do escritor em fazê-lo - o que não poderia nunca ser comprovado - mas na observação da construção particular do texto e da relação possível entre a carta, os ensaios, a teoria e o romance naturalista.

8 Tradução da autora.

${ }^{9}$ Tradução da autora.
} 
de conquista da "audiência" da carta. Porém, a perspectiva a ser delineada no presente texto é a de apontar para os elementos do estilo na missiva tendo como ponto de partida uma leitura inspirada na análise narrativa de Leo Spitzer, para quem o aspecto estilístico e o elemento estruturante.

Fortemente influenciado pela hermenêutica romântica, o método de análise desenvolvido pelo austríaco Leo Spitzer fornece elementos para o estudo de uma obra de arte a partir de um elemento chave - normalmente um trecho fundamental da obra - que configure um desvio substancial, mas que seja ao mesmo tempo passível de relação com um sistema. Esse sistema seria então relacionado a um contexto mais amplo na relação com o universo do autor e do seu mundo. Apesar de ter sofrido muitas críticas quanto à arbitrariedade de sua leitura pessoal, assim como quanto ao viés psicologizante de sua análise e de ter, ele próprio, rejeitado em parte a perspectiva psicológica ${ }^{10}$, o método spitzeriano fornece elementos suficientes para colocar em relevo algum aspecto constituinte do texto e relacioná-lo com o todo equivalente - autor e contexto.

A amplitude da metodologia spitzeriana pode ser medida pela gama de fontes de análise que o autor realizou em vida. Aplicou a mesma estrutura de pensamento e interpretação da obra até mesmo em artigos de jornal, como é o caso do artigo "Frz. Votersocialiste", no qual a variação do votar socialista a partir de votar no partido socialista configura a chave de análise do texto (SPITZER, 1938). No caso da análise de J'accuse, o método será fundamental principalmente em duas etapas. Em primeiro lugar, a relação entre desvio e motivação do autor e, na sequência, o desdobramento deste desvio no contexto político da época e no tripé da obra zoliana.

Argumentum: Um elogio, dois processos, uma situação e uma acusação. Assim pode ser resumido, de forma geral, o conteúdo de J'accuse. Zola inicia a missiva com um agradecimento e um elogio ao presidente destinatário e trata do processo militar e da revisão do processo Dreyfus, recém-finalizada na cidade de Rennes. Em seguida, expõe a situação do momento e enumera uma lista de acusações. Diante desta estrutura geral e tendo como ponto de partida a busca de um elemento distintivo na carta - potencialmente portador de outras relações - dois aspectos chamam particularmente a atenção: a construção da personalidade de du Paty de Clam, tenente-coronel encarregado da primeira investigação - e, segundo Zola, o grande "obreiro" do caso - e a profusão de adjetivos que polarizam a dada situação em dois polos, que chamarei doravante de luminoso e sombrio. Passemos, portanto, às citações.

\section{RETÓRICA DOS PERSONAGENS}

\footnotetext{
${ }^{10}$ Ver itinerário completo da obra com bibliografia selecionada em WELLEK (1960).
} 
Un homme néfaste a tout mené, a tout fait, c'est le colonel du Paty de Clam, alors simple commandant. Il est l'affaire Dreyfus tout entiére, on ne la connaîtra que lorsqu'une enquête loyale aura établi nettement ses actes et ses responsabilités. Il apparaît comme l'esprit le plus fumeux, le plus compliqué, hanté d'intrigues romanesques, se complaisent aux moyens des romans-feuilletons, les papiers volés, les lettres anonymes, les rendez-vous dans les endroits déserts, les femmes mystérieuses qui colportent, de nuit, des preuves accablantes.

\section{(...)}

Mais, au fond, il n'y a d'abord que le commandant du Paty de Clam, que les mène tous, qui les hypnotise, car il s'occupe aussi de spiritisme, d'occultisme, il converse avec les sprits. On ne croira jamais les expériences auxquelles il a soumis le malheureux Dreyfus, les pièges dans lequels il a voulu le faire tomber, les enquêtes folles, les imaginations monstrueuses, toute une démence torturante.

\section{(...)}

Et l'instruction a été faite ainsi, comme dans une chronique du quinzième siècle, au milieu du mystère, avec une complication d'expédients farouches...

\section{(...)}

C'est que du secours lui était venu, il avait reçu une lettre anonyme l'avertissant des menées de ses ennemis, une dame mystérieuse s'était même dérangée de nuit pour lui remette une pièce volée à l'état-major, qui devait le sauver. Et je ne puis m'empêcher de retrouver là le lieutenant-colonel du Paty de Clam en reconnaissant les expédients de son imagination fertile. Son œuvre, la culpabilité de Dreyfus était en péril, et il a voulu sûrement défendre son oeuvre. La révision du procès, mais c'étaitl'écroulement du romanfeuilleton si extravagant, si tragique, dont le dénouement 
abominable a lieu à l'île du Diable! C'est ce qu'il ne pouvait permettre. ${ }^{11}$

O primeiro trecho citado aparece após a seguinte sentença: "La verité d'abord sur le procès et sur la condamnation de Dreyfus". Logo depois do anúncio da verdade, não há fatos, nem provas, há somente um homem nefasto, que aparece como um espírito nebuloso, complicado. Em toda a missiva, du Paty de Clam aparece como o criador da obra, o grande autor do caso Dreyfus. Mas como entender que exista um grande culpado se na quarta parte da carta a situação que nos apresenta Zola - e a que mais torna a situação compreensível para o leitor - é a do meio corporativo como responsável pelo imbróglio criado a partir de um erro que não se pode revelar sem que todo o exército seja corresponsabilizado por ele? $\mathrm{E}$ como entender que uma só pessoa tenha criado a situação se a acusação final envolve dez pessoas nominalmente?

O primeiro elemento interessante que Zola faz uso, portanto, é o da personificação do caso: "Il est l'affaire Dreyfus tout entiére". O tenente-coronel não investigou o caso, não estudou o caso, ele é o caso. Portanto, o caso Dreyfus é também uma criação romanesca de du Paty de Clam. Tudo é construído como em um ambiente de folhetim: "Et l'instruction a été faite ainsi, comme dans une chronique du quinzième siècle, au milieu du mystère, avec une complication d'expédients farouches”. A crítica de Zola à forma como foi conduzido o caso não se dirige para os fatos ou provas - mesmo porque nenhum dos lados desta disputa dispunha de provas concretas acerca da culpabilidade ou inocência de Dreyfus - mas ao autor de uma obra. É uma crítica literária, num primeiro momento, uma crítica à obra criada por du Paty de Clam, que muito se assemelha às batalhas de Zola pelo impressionismo na pintura ou pela naturalismo na literatura. Mas aqui, ao mesmo tempo em que rejeita a imaginação gratuita de du Paty de Clam, Zola se utiliza de

\footnotetext{
${ }^{11}$ Um homem nefasto a tudo conduziu, tudo fez: o coronel du Paty de Clam, então simples comandante. Ele é todo o caso Dreyfus, e a verdade só será conhecida quando uma investigação leal tiver estabelecido abertamente seus atos e responsabilidades. Ele aparece como o espírito mais nebuloso, o mais complicado, assombrado por intrigas romanescas, deleitando-se com os ambientes de folhetim, documentos roubados, cartas anônimas, encontros em lugares desertos, mulheres misteriosas que propagam, na noite, provas esmagadoras (...) Mas, no fundo, não existe ninguém a não ser o comandante du Paty de Clam, que conduziu a todos, que os hipnotizou, pois ele se ocupa também do espiritismo e das ciências ocultas, ele conversa com os espíritos. Não poderemos nunca acreditar nas experiências as quais ele submeteu o infeliz Dreyfus, nas armadilhas nas quais ele procurou fazê-lo cair; nas suas imaginações monstruosas, toda uma demência torturante (...) E a instrução foi feita assim, como em uma crônica do século $\mathrm{XV}$, envolto em mistério, com uma miríade de recursos ilícitos (...) É que o socorro havia chegado, ele recebera uma carta anônima informando-o das manobras de seus inimigos, uma dama misteriosa tinha até mesmo se perturbado durante a noite para entregar-lhe um documento roubado do estado-maior, que devia salvá-lo. E reconhecendo os expedientes de sua fértil imaginação, não posso deixar de ver nesse episódio o tenente-coronel du Paty de Clam. Sua obra, a culpabilidade de Dreyfus, estava em perigo, ele queria seguramente defendê-la. A revisão do processo! Mas seria a ruína do seu romance-folhetim tão extravagante, tão trágico, cujo desfecho abominável acontecia na ilha do Diabo! Isto, ele não podia permitir."Os trechos da carta e sua tradução foram tirados de ALMEIDA (2009).
} 
estratégias semelhantes para angariar a simpatia do leitor de jornal, particularmente ao construir um personagem tal qual nos romances de folhetim.

Portanto, o que nos é apresentado é um personagem de romance ao lado da figura real deste encarregado das primeiras instruções do processo Dreyfus, o coronel Armand du Paty de Clam. É preciso ter em perspectiva neste caso a concepção de Zola sobre o homem e sua obra para entender um pouco melhor a construção desta personagem. Isto porque para o autor de Germinal, não há separação entre autor e homem, obra e vida. Em artigo publicado no dia $1^{\circ}$ de junho de 1868 , no L'Evénement Illustré ${ }^{12}$, "Os paisagistas" ${ }^{3}$, há um trecho de acusação aos artistas paisagistas que mostra o caráter indissociável entre o artista e o homem em Zola:

Eu os acuso sobretudo de carecerem de personalidade. Eles se copiam uns aos outros, ou melhor, criaram uma natureza de convenção, talhada segundo o molde da grande natureza, e é essa natureza que encontramos em todos os seus quadros, indistintamente. Os naturalistas de talento, pelo contrário, são intérpretes pessoais; traduzem as verdades em línguas originais, conservando sempre a sua individualidade. São humanos antes de tudo, e impregnam com essa humanidade o menor tufo de folhagens que pinta. É isso que fará com que suas obras vivam. (ZOLA, 1989: 119)

Ao criar uma personagem romanesca sem o traço de realidade ou sem a humanidade que o faria único, Zola faz de Paty de Clamuma natureza de convenção, construída apenas na imaginação sem uma fagulha do real. Ele é o criador de um erro, de uma falsificação do real, e buscou a todo custo mantê-lo, enquanto poderia ter feito como o fizeram o tenente-coronel Picquart e o senador ScheurerKestener: "deux braves gens, deux coeurs simples". Se não o fez, porém, não foi somente pela sua obra que estava em perigo: "Son œuvre, la culpabilité de Dreyfus était em péril, et il a voulu sûrement défendre son œuvre”, mas porque como homem não estava entre aqueles que buscam a verdade e a defendem. Ele fazia parte do mundo contra o qual Zola lutava no caso Dreyfus e durante toda a sua vida, um mundo construído apenas na imaginação, sem nenhum lastro na realidade. Toda a obra romanesca de Zola parte de pesquisas no ambiente em que se passará a história. Paty de Clam não cria uma obra calcada no real, portanto, ela é a princípio falsa. Mas a importância deste personagem na missiva está justamente neste uni-

\footnotetext{
12 Zola começou a colaborar com o L'EvénemetIllustreem 1868 e sua maior contribuição para o periódico foi uma série de crônicas, cujos temas iam desde o nível dos fait-divers à crítica literária. Duas destas crônicas tratam de episódios que foram posteriormente incorporadas em dois romances da série dos Rougon-Macquart, La Faute de L'AbbéMouret e La Conquête de Plassans. Estas informações sobre a atividade jornalística de Zola foram retiradas de HEMMINGS (1956).

${ }^{13} \mathrm{O}$ texto citado foi incorporado à coletânea sobre o impressionismo publicada no Brasil. Ver ZOLA (1989).
} 
verso falseado, base do mundo dual construído na carta, cuja estrutura está na profusa adjetivação aí presente.

\section{ADJETIVAÇÃo}

Todas as qualificações atribuídas a Paty de Clam são de caráter atributivo, passíveis de serem utilizados para qualquer outro personagem ou situação na carta ${ }^{14}$ : "néfaste, fumeux, compliqué", sobre o tenente-coronel; romanesques (intrigues), volés (papiers), anonymes (lettres), déserts (endroits), mystérieuses (femmes), accablantes (preuves)", sobre diversos nomes (inseridos entre parênteses). É possível observar que os adjetivos atribuídos a du Paty de Clam evocam uma certa nebulosidade. O termo "néfaste" marca a ideia de algo funesto, mau, perigoso, "fumeux" evoca uma ausência de claridade, uma obscuridade, por fim, "compliqué" guarda aqui o sentido de confusão, de algo difícil de compreender. Mesmo os termos atribuídos a outros nomes, mas ligados à "obra" do tenente-coronel guardam o mesmo conjunto de imagens: "volé", retirados de algum lugar visível; "anonymes", com origem escondida, não revelada; "déserts", inabitado, "mystérieuses, enigmático, impenetrável; “accablantes”, destruidoras.

Por outro lado, quando se refere ao senador Scheurer-Kestner, ao tenentecoronel Picquard, ao presidente Felix Faure (salvo o uso da ironia em alguns momentos) ou a si mesmo, as atribuições invertem os lados. Sobre Scheurer-Kestner, diz Zola:

Il a été le grand honnête homme, l'homme de sa vie loyale, il a cru que la vérité se suffisait à elle-même, surtout lorsqu'elle lui apparaissait éclatante comme le plein jour. A quoi bon tout bouleverser, puisque bientôt le soleil allait luire ? Et c'est de cette sérénité confiante dont il est si cruellement puni.

Ou, sobre o tenente-coronel Picquart:

De même pour le lieutenant-colonel Picquart, qui, par un sentiment de haute dignité, n'a pas voulu publier les lettres du général Gonse. (...) Il y a deux victimes, deux braves

\footnotetext{
${ }^{14}$ De acordo com José Borges Neto, os adjetivos atributivos ou modificadores de referente têm sentido independente e podem ser transferidos para qualquer outro nome. Já os predicativos não são transferíveis e indicam uma propriedade do nome. Para efeito de análise, os adjetivos utilizados para desenvolver esta parte do trabalho serão exclusivamente atributivos, já que se busca compreender a construção de dois mundos polarizados, mas não essenciais. As observações sobre os adjetivos foram retiradas de BORGES NETO (1991).
} 
gens, deux cœurs simples, qui ont laissé faire Dieu, tandis que le diable agissait. ${ }^{15}$

"Grand, honnête, loyale (vie), confiante (sérénité)" para um; "haute (dignité)" para o outro. "Braves, simples (coeurs)" para ambos. Mais do que contrapor bons e maus, Zola cria dois universos, dois ambientes. Para du Paty de Clam, o lado sombrio, para os homens de bem, o luminoso. A oposição entre bondade e maldade está associada à mesma polarização de luz e sombra. Inclusive, dentre os homens de bem e honestos está o próprio autor da carta. O termo "honnête" aparece na carta cem cinco situações. Na primeira delas, o termo se refere ao próprio autor: "Etc. est à vous, monsieur le Président, que je la crierai, cette vérité, de toute la force de ma révolte d'honnête homme." A segunda utilização do adjetivo referese aos homens honestos que lerão o ato de acusação de Dreyfus como um prodígio de iniquidade. Em seguida, nas outras três ocorrências, Zola se dirige ou ao tenente-coronel Picquard ou ao senador Scheurer-Kestner.

O último lado luminoso deste jogo de qualificações guarda alguns traços de ironia que o distinguem dos demais. Dirigem-se ao destinatário oficial da carta, o então presidente da República francesa, sr. Felix Faure. Porém, os adjetivos quase nunca recaem sobre a pessoa do presidente. Na única exceção: "Vous apparaissez rayonnant.”, a adjetivação não está ligada à pessoa de Felix Faure, mas sim ao cargo por ele ocupado. Este tipo de qualificação - quando o termo funciona na frase como adjunto adnominal - não encerra um atributo da pessoa, como o quer dar o autor, mas sim um predicado do nome, no caso, da função. $\mathrm{O}$ adjetivo modifica, neste caso, a referência, o presidente em geral, não a pessoa que exerce o cargo. Não é uma qualificação dada por Zola é uma situação dada pelas circunstâncias, que são, no caso, a aliança russa firmada recentemente pela França e a Exposição Universal de 1900. Os outros adjetivos atributivos que aparecem ligados à figura do presidente são sempre indiretos: "votre étoile, si heureuse jusqu'ici, est menaçée de la plus honteuse, de la plus ineffaçable des taches?”. Portanto, o presidente, neste mundo dual, estaria em uma espécie de "limbo", no qual somente sua atitude como verdadeiro homem honesto iria resgatá-lo, como atesta o seguinte trecho no final da carta: "Vous n'en avez pas moins um devoir d'homme, au quel vous songerez, et que vous remplirez".

Luz e sombra, honestidade e desonestidade. São estas as duas polarizações que se associam. O mundo luminoso na carta está diretamente relacionado ao universo dos homens honestos, assim como o desonesto ao sombrio. Como técnica narrativa, aproxima-se muito da investigação da relação entre luz e sombra presente

\footnotetext{
${ }^{15}$ Ele tem sido o mais honesto dos homens, o homem de uma vida leal; ele acreditou que a verdade bastava por si mesma, sobretudo quando ela the apareceu reluzente como a luz do dia. Para que tudo perturbar, se logo o sol tornaria a luzir? E é por essa serenidade confiante que ele é agora tão cruelmente punido.

O mesmo se deu com o tenente-coronel Picquart, que, por um sentimento de alta dignidade, não quis publicar as cartas do general Gonse (...). Há duas vítimas, dois bravos homens, dois corações simples, que confiaram em Deus, enquanto o diabo agia. (ALMEIDA, 2009)
} 
nos ensaios de Zola sobre os salões de pintura e particularmente sobre Claude Monet.

Ao escrever sobre os salões de pintura, particularmente em alguns artigos publicados em maio de 1868, no l'Evénement Illustré, Zola vê o mundo de uma perspectiva dual, entre um universo luminoso e outro sombrio, sempre associados à figura do artista. De um lado, "As salas estendem-se, cinza, monótonas, cheias de placas com manchas desagradáveis e berrantes como os buquês de flores impressos nos fundos neutros dos papéis de parede", e, de vez em quando, "só muito raramente", alguma tela "abre para fora, para a verdade; o arco-íris berrante dos quadros vizinhos desaparece e conseguimos respirar um pouco de ar puro..." (ZOLA, 1989: 97). Luz e verdade aparecem intrinsicamente ligadas, assim como em J'accuse. É claro que estando aqui num universo particularmente propício ao universo temático da iluminação, o escritor prescinde da profusão de adjetivos que dão o tom da carta aberta. Ainda assim, trata-se de um caminho, o da verdade, como no trecho sobre as telas de Camille Pissarro, pintor impressionista francoholandês:

Em meio a essas telas embonecadas, as telas de Camille Pissarro parecem de uma nudez desoladora (...) O artista só se preocupa com a verdade, com a consciência; ele se coloca diante de uma porção da natureza, impondo-se como tarefa interpretar os horizontes na sua severa largueza, sem tentar colocar aí o menor regalo de sua invenção (...)

Basta dar uma olhada nessas obras para ver que nelas há um homem, uma personalidade firme e vigorosa, incapaz de mentiras, fazendo da arte uma verdade pura e eterna (...) (ZOLA, 1989: 99)

A nudez desoladora das telas de Pissarro está diretamente relacionada à consciência do artista na pena de Zola. Nelas, vemos o homem incapaz de mentiras realizando uma arte de "verdade pura e eterna". São dualidades semelhantes agora também adjetivadas, pois ligadas ao homem e não somente à pintura - que Zola se utiliza também na defesa do capitão francês Dreyfus. Zola dialoga com seu tempo por meio de inúmeras oposições, repetidas também na sua teoria do romance. De um lado, o senso do real, a pujança da vida descrita nas obras literárias, pintada nos quadros impressionistas; de outro, a expressão pessoal, a figura do artista criador. Não há mais a figura do gênio, cuja criação transcende a personalidade, há homens que, como Zola, acreditam no progresso, na ciência e no desenvolvimento inexorável do homem. Um homem em diálogo com seu tempo, cujo universo dispõe o mundo como uma batalha constante: uma batalha para a consa- 
gração, uma batalha pelos injustiçados, pelos artistas não reconhecidos. No limite, pelo seu próprio reconhecimento como francês legítimo ${ }^{16}$.

\section{ZOLA E SEU TEMPO}

Apesar de suas posições firmes e do embate constante, Émile Zola nunca serviu a qualquer grupo político. Na crítica socialista ou anarquista, a atenção dada à sua obra foi episódica até 1880 , com sua luta pelos republicanos: "Sa vive rupture, en 1880, avec les politiciens républicains, (...) lui suscite certes des sympathies dans une extrême-gauche dont la renaissance publique commence avec le retour des Communards déportes" (REBERIOUX,1968: 08). Com L'Assomoir, de 1877, Zola foi alvo de duras críticas da esquerda, mas com Germinal, de 1885, voltou a ser bem quisto entre socialistas e comunistas.

Sua posição sobre os "communards" dá a dimensão desta posição de autonomia crítica. Ao buscar entender a posição de Zola sobre a comuna, a partir do romance La Débâcle, de 1892, Roger Ripoll conclui que Zola nunca foi favorável à Comuna: "Pour Zola, les Communards sont des inconscients" (RIPOLL, 1968: 22). O mesmo contraste que ele vê nos homens da Comuna, entre o líder e a massa, aparece no retrato da multidão que não consegue apreciar o quadro de um naturalista: "Para os olhos sem inteligência da multidão, acostumados com as lantejoulas dos quadros vizinhos, elas são mortiças, cinzas, mal-acabadas, grosseiras e rudes." (ZOLA, 1989: 109).

E por que, então, dada a sua atitude política de enfrentamento e debate, Zola não adere a nenhuma corrente definitiva? A resposta é simples: pois ele cria a sua própria corrente. E o momento do caso Dreyfus é particularmente importante nesta definição. André Daspre, ao examinar a relação entre Zola e os intelectuais durante o caso, chega a esta conclusão certeira: "De ce point de vue l'Affaire Dreyfus doit être considérée comme um moment de la lutte idéologique menée par les rationalistes, et um moment três importante puisqu'ils se trouvent alors obligé de préciser leur doctrine et de se rassembler pour agir" (DASPRE, 1968: 44) ${ }^{17}$. E Zola, particularmente neste contexto, reafirma sua teoria, sua crítica e sua obra. O novo, a partir deste momento, é que o grande personagem, a sua grande construção mitológica, é também ele mesmo. A sua própria vida se transforma em uma história e em um drama, chegando ao limite das dúvidas que pairam acerca das circunstâncias de sua morte.

\footnotetext{
${ }^{16}$ Zola tem dupla nacionalidade: origem italiana, por parte de pai e francesa, pela mãe. Só na idade adulta é que obtém a cidadania francesa. Durante o caso Dreyfus, a sua origem italiana é muitas vezes lembrada de forma bastante crítica.

17 Deste ponto de vista, o caso Dreyfus deve ser considerado como um momento da luta ideológica conduzida pelos racionalistas, um momento muito importante, pois agora eles se viam obrigados a explicita suas doutrinas e se juntar na ação (tradução própria).
} 


\section{MITOLOGIA PANFLETÁRIA}

Este aspecto dramático, que aparece na carta pelos recursos de personificação dos atores reais do processo e na adjetivação como forma de construção de um espaço dualístico, aparece em toda a obra de Zola. A transformação dos personagens em representações condensadas da realidade, como Nana, cristalização da figura da prostituta, ou, em menor escala, Serge Mouret, o padre Mouret em La Faute de l'abbé Mouret, como a tipificação do homem religioso em conflito com o prazer da carne, repetem-se seja na sua obra de polêmica, seja na defesa do capitão condenado. Junito de Souza Brandão, em Mitologia Grega, constrói uma metáfora da ideia de mito escrito que corresponde à forma de elaboração escrita de Zola. Para ele, "um mito escrito está para um mito 'em função', como uma fotografia para uma pessoa viva" (BRANDÃO, 1993: 25). O que Zola polariza em J'accuse, nos textos em defesa dos impressionistas e, mesmo em sua obra literária, é uma fotografia em preto e branco, em claro e escuro, cujas imagens figuram como metáfora de uma visão da humanidade a caminho do esclarecimento, por meio da ciência e do conhecimento.

Dois trechos curtos do romance La faute de l'abbé Mouret ilustram a mesma relação fotográfica entre claro e escuro, entre luz e sombras. A história do romance é dividida em três partes. Na primeira, o excesso de devoção e a crise com seus desejos leva o padre Mouret a um estado de loucura e doença. Em seguida, ele aparece cuidado por Albine, uma jovem pela qual ele se apaixona. Neste período da vida, longe de tudo e todos, ele vive com Albine o amor em meio aos belos jardins ao redor da residência. Na última parte, Mouret retorna ao exercício da função de padre, abandona Albine e busca esquecer os pecados da carne. Os trechos a seguir são da segunda e terceira partes, o primeiro um retrato dos jardins de Albine, o segundo, no presbitério:

Les bouquetes de saules, tout là-bas, semblaient d'or pur, au milieu du grand frisson de la lumière. Des poussières dansantes mettaient aux pointes des gazons un flux de clartés, tandis qu'à certains souffles de vent, passant librement sur cette solitude nue, les herbes se moiraient d'un tressaillement de plantes caressées (ZOLA, 1960: 1369)

\section{(...)}

Lui (l'abbé Mouret), un tablier bleu serré à la taille, les poignets meurtris, s'absorbait dans cette rude besogne, avait un prétexte pour ne plus sortir. Il vivait ses journées au milieu des plâtras, plus tranquille, presque souriant, oubliant 
le dehors, les arbres, le soleil, les vents tièdes, qui le troublaient (ZOLA, 1960: 1435) ${ }^{18}$

Estes dois pequenos trechos são uma espécie de retratos de dupla situação. $\mathrm{Na}$ primeira tudo aparece vivo, "du grand frisson de la lumière", "certains souffles de vent", "des poussières dansantes". E a luz cria este elemento de vida como "un flux de clartés". A sua contra-imagem vem da segunda situação, na qual o padre Mouret se enclausura no trabalho, deixando de lado tudo que o torna vulnerável. O retrato da dualidade de Mouret, entre o serviço religioso e a paixão por Albine apresenta-se diante do leitor, na imagem maior da natureza e da clausura, como símbolos imagéticos das dúvidas existenciais do personagem. Nesta segunda citação, Mouret está de volta ao presbitério e se mantém distante do elemento vivo do lado de fora, a rua, o vento, o sol. Uma situação é a antítese da outra, como a luz e a sombra, ou como muitas das dualidades criadas por Zola.

A fotografia, assim como a pintura, foi de fato, um dos grandes interesses na vida de Émile Zola. No fim do século XIX, a fotografia conheceu uma grande popularidade e Zola - um apreciador das inovações científicas - reconheceria na técnica as boas-novas do progresso. Ele comprou nada menos que dez aparelhos e instalou, no subsolo de suas diferentes residências, três laboratórios onde ele mesmo revelava seus negativos. De 1895 até sua morte, em 1902, Zola fez inúmeras fotos. Durante o exílio na Inglaterra, pela condenação no caso Dreyfus, em 1898, é em grande parte pelas fotografias tiradas pelo escritor que se pode reconstituir sua vida durante o período de exílio.

A imagem em preto e branco no contraste de luz e sombra da fotografia encaixa-se como uma luva na forma zoliana de observar o mundo, na dualidade com que recria as imagens que capta do real. Retomando a relação entre fotografia e real e mito escrito e mito "em função", é Mitterand que observa como a imagem do mito está presente em $J$ 'accuse:

A verdade triunfaria, pois a assinatura do gênio soube dar a ela a força de ficção. Para mobilizar a opinião, Zola compreendera que ele devia deslocar o caso da política e das noticias cotidianas, para dar-lhe uma dimensão quase poética. É que há muito tempo ele sabia da superioridade do poético sobre o político, ou que, de toda maneira, o controle da cidade só se podía obter com o domínio absoluto da palavra. Pelo contrário, é o poder político que tem sempre na palavra de um grande escritor o contraponto que o equilibra, e a quem ele respeita. (MITTERAND, 1990: 249)19

\footnotetext{
${ }^{18}$ Em função da maior elaboração da linguagem nos romances, optou-se aqui por manter somente no original os trechos.

${ }^{19}$ Tradução da autora.
} 
Portanto, Zola constrói em J'accuse uma narrativa imbuída dos mesmos elementos que ele dispõe em sua obra e em sua vida. Empresta às imagens dos atores (du Paty de Clam) e dos dois polos (dreyfusards e antidreyfusards) os mesmos artifícios de construção presente na sua obra de polêmica e nos romances, qual seja, a elaboração de imagens fotográficas de luz e sombra que dão à realidade uma existência que se aproxima do mito narrado. Ou seja, uma existência poética, dando o status de mito aos personagens e às situações polarizadas. Esta mesma mitologia que mobiliza o fator hereditário (como construção científica do real) e a intuição, ou o senso do real e a expressão pessoal, confere a J'accuse a mistura entre poética e política, de um tipo de mitologia panfletária, a meio caminho entre jornalismo e literatura.

\section{CONCLUSÕES EN PASSANT}

A palavra "romance" incomodava Zola. Ele pensou em substituí-la por "estudo" ou "relatório". A idéia almejada era trocar a imaginação gratuita pelo enfoque científico. A intenção era criar uma nova estética, o naturalismo. Para isso, imagens fixadas faziam-se necessárias ou, ao menos, desejáveis. Quando escreveu J'accuse, Zola já era um escritor consagrado. Sabia, certamente, que para convencer a França da inocência do capitão Dreyfus não podia contar com provas, até porque não as tinha. Contava somente com sua pena e com seus recursos de linguagem como polemista, crítico e romancista. E fez uso de todos os recursos que, ao final, partiam, em grande medida de um princípio único: a construção de um quadro de dois polos constitutivo de um mundo dual e elevado à categoria de mito pela inscrição do quadro geral em um todo completo.

Por meio dos recursos de personificação de Paty de Clam e da adjetivação como constituidora dos dois polos, Zola elaborou em J'accuse um retrato fiel de seu mundo dual. Contrapõe dreyfusards e antidreyfusards como polos da verdade e da mentira, da luz e da sombra e elabora, assim, um retrato muito semelhante ao que faz como polemista, em prol dos impressionistas, como teórico naturalista e como romancista. Nesta foto em preto e branco, ele inscreveu o mito em sua fixação momentânea, atualizável como retrato da injustiça humana. Isso porque ao elaborar o discurso como mito, ele ao leitor a constante possibilidade de renovação. Não é por acaso que ainda hoje, suas palavras ecoam nos discursos políticos.

Recentemente, um líder do governo brasileiro, o sr. Romero Jucá, utilizou o título da carta de Zola, de forma inadequada e desprovida de contexto. Associou-a ao contexto de denuncismo nos anos mais radicais da Revolução Francesa ao período atual de prisões preventivas e acusações sem lastro. De um lado, o caráter mitológico de J'accuse pode ensejar tais apropriações. Porém, e infelizmente para os atuais oradores, a defesa final nem sempre os inocenta, como aconteceu com o capitão Dreyfus. De outro lado, porém, reflete a força de construção de um texto 
que ultrapassa seu momento de criação, como as grandes obras artísticas. Enfim, na forma e no conteúdo, trata-se de um texto único, pelo seu estilo e sua força de polarização.

\section{REFERÊNCIAS BIBLIOGRÁFICAS}

ALMEIDA, M. Melodrama bacharelesco: um estudo estilístico da recepção do caso Dreyfus no Brasil. Dissertação (mestrado) - Universidade Estadual de Campinas, Instituto de Estudos da Linguagem Campinas, São Paulo: [s.n.], 2009.

ARENDT, H. "The Dreyfus Affair”, IN: ARENDT, Hannah. The Origins of Totalitarianism. San Diego/New York/London: Harvest Book, 1976.

BORGESNETO, J. Adjetivos: predicados extencionais e predicados intencionais. Campinas: Editora da Unicamp, 1991 (série Teses).

BRANDÃO, J.S. Mitologia Grega, volume I. Rio de Janeiro: Petrópolis: Ed. Vozes, 1993.

BREDIN, J. O Caso Dreyfus. São Paulo: Companhia das Letras, 1993.

DASPRE, A. “Zola et les intellectuels”. Europe, 46º Anné, n 468-469, avril-mai, 1968.

HEMMINGS, F.W.J. "Zola's apprenticeschip to Journalism(1865-70)”. PMLA, 71, $\mathrm{n}^{\circ}$ 3, jun. 1956.

MITTERAND, H. Zola: l'histoire et la fiction. Paris: Presses Universitaires de France (PUF), 1990.

PAGÈS, A. "La Rhetoric de J'Accuse". IN MILLOT, Hélène \&SAMINDAYARPERRIN, Saint-Etienne (orgs). Spectacles de la parole. Éditions des Cahiers intempestifs, 2003. Disponível em: http://www.item.ens.fr/index.php?id=187352.Acessado em: 20/02/2008.

REBÉRIOUX, M. "Zola et la critique littéraire française socialiste et anarchiste". Europe - RevueMensuelle, 46 Anné, no 468-469, avril-mai, 1968.

RIPOLL, R. "Zola et les communards". Europe - Revue Mensuelle, 46 Anné, n 468-469, avril-mai, 1968. 
RICOEUR, P. Teoria da Interpretação. Lisboa: Edições 70, 1987.

SCHMITZ, D. "La théorie de l'artepistolaire et de la conversationdans la tradition latine et néolatine" IN BRAY, B STROSETZKI, C. Art de la lettre, Art de la conversation à l'époqueclassique en France. Actes du colloque de Wolfenbüttel, octobre, 1991.

SPITZER, L. “Frz. Voter socialiste”. NeuphilologischeMitteilungen Bd. 39 (1938). Linguistic and LiteratyHistory.New York: Russell \& Russell, 1962.

TYNIANOV, J. “Da evolução literária”. In: TODOROV, Tzvetan (apres.), Teoria da Literatura I, Textos dos Formalistas Russos, Edições 70, Colecção Signos, nº15, Lisboa, 1978.

WELLEK, R. "Leo Spitzer (1887-1960)”. ComparativeLiterature, vol.12, n 4, Autumn 1960; p. 310-314.

- A batalha do impressionismo. Rio de Janeiro: Paz e Terra, 1989. . "La Faute de l'abbé Mouret". In: Les Rougon-Maquart-Histoire naturelle et sociale d'une famille sous le second Empire. Volume I. Paris: ÉditionsFasquelleetGallimard, 1960.

ÉMILE-ZOLA ET MASSIN, F.. Zola photographe - 480 documents choisis et présentés par François Émile-Zola et Massin. Paris: Denoël, s/d. 